\title{
Analisis Pengaruh Piutang Tak Tertagih Terhadap Profitabilitas Pada Perusahaan CV. Anugrah Sriwijaya Sukses
}

\author{
Yapet Tanuma \\ Universitas Indo Global Mandiri \\ Email: yafettanuma@gmail.com
}

\begin{abstract}
This study aims to analyse the effect of the ratio of arrears and collectors to return on assets at CV Anugrah Sriwijaya Sukses. This research is descriptive quantitative. Data were obtained through interviews with company leaders and employees related to the finance department and looking at financial report data for the 2017-2019 period. Data were collected using purposive sampling method and analysed using multiple linear regression. The findings evidence that partially, arrears have an effect on return on assets, and the ratio of collectors has no effect on return on assets. Simultaneously, the ratio of arrears and collectors simultaneously have a positive and significant effect on return on assets at CV Anugrah Sriwijaya Sukses.
\end{abstract}

Keywords: uncollectible receivables, profitability, ROA, arrears ratio, collection ratio

\section{Pendahuluan}

Pada dasarnya setiap perusahaan baik yang bergerak di bidang dagang, jasa maupun manufaktur memiliki tujuan yang sama yaitu untuk memperoleh laba dan menjaga kesinambungan perusahaan di masa yang akan datang. Secara umum, keberhasilan suatu perusahaan dalam menjalankan aktivitasnya seringkali didasarkan pada tingkat laba yang diperoleh. Akan tetapi laba yang besar belum tentu menjadi ukuran bahwa perusahaan tersebut telah bekerja secara efisien. Tingkat efisiensi baru diketahui dengan cara membandingkan laba yang didapat dengan kekayaan atau modal yang menghasilkan laba tersebut (profitabilitas) (Riyanto, dalam Iskandar, 2016). Profitabilitas merupakan kemampuan suatu perusahaan dalam melakuakn aktivitasnya menghasilkan laba melalui sumber daya yang dimiliki oleh perusahaan. Dalam jurnal yang berjudul Pengaruh Beban Piutang Tak Tertagih Terhadap Return On Assets (Studi pada PT PLN (Persero) Distribusi Jawa Timur Area Malang Pada Periode Tahun 2009-2016. (Rositah, Handayani, 2018).

Penjualan adalah suatu kegiatan dimana perusahaan atau penjual menyerahkan barang atau jasa kepada pembeli, dan kemudian pembeli melakukan pembayaran atas barang atau jasa yang diterimanya dengan cara tunai atau kredit. Dalam melakukan penjualan kredit, perusahaan perlu mempertimbangkan resiko yang mungkin akan terjadi. Karena penjualan secara kredit memungkinkan adanya pelanggan atau konsumen yang menunggak pembayaran piutangnya, dikarenakan ketidakmampuan atau sengaja tidak membayar kewajibannya. Sehingga menimbulkan piutang yang tidak dapat ditagih yang dalam akuntansi dikenal dengan nama piutang tak tertagih.

Dalam penelitian ini piutang tak tertagih akan diukur dengan menggunakan rasio tunggakan, dan rasio penagih. Menurut (Kewon, dalam Diana, Noviana, 2016) rasio tunggakan ini dapat digunakan untuk mengetahui berapa besar jumlah piutang yang telah 
jatuh tempo dari sejumlah penjualan kredit yang belum tertagih. Sedangkan rasio tunggakan (Kewon, dalam Diana, Noviana, 2016) rasio penagihan bertujuan untuk mengetahui berapa besar piutang yang tertagih dari total piutang yang dimiliki perusahaan. Di dalam penelitian ini profitabilitas akan diukur dengan mengunakan Retun On Asset (ROA). Menurut (Hery, dalam Egam dkk, 2017) ROA adalah rasio yang menunjukan kontribusi aset dalam menciptakan laba bersih. CV. Anugrah Sriwijaya Sukses merupakan salah satu perusahaan yang bergerak dalam bidang industri pemasok kayu aksia di daerah Sumatera Selatan. Perusahaan ini otomatis akan senantiasa meningkatkan hasil produksinya baik dalam hal kuantitas terlebih lagi dalam hal kualitas guna dapat bersaing di pasaran sehingga dapat memperluas pangsa pasar.

Penawaran kayu akasia terhadap penampung dilakukan dengan pembelian secara cash dan banyak juga dari penampung yang melakukan pembelian kayu secara kredit untuk meningkatkan penjualan dari CV Anugrah Sriwijaya Sukses. Akibatnya timbul piutang dengan resiko terbesarnya berupa tak tertagih. Terkait dengan pengendalian internal terhadap piutang yang di terapkan oleh manajemen CV. Anugrah Sriwijaya Sukses masih terdapat beberapa kelemahan dalam metode penerapannya, baik belum terlaksananya penagihan maksimal terhadap piutang tak tertagih hingga pada kebijakan aturan piutang, khususnya piutang tak tertagih yang tidak tegas dari perusahaan, yang mengakibatkan meningkatnya jumlah piutang tak tertagih. Berdasarkan data empiris piutang tak tertagih pada CV. Anugrah Sriwijaya Sukses.

Tabel 1. Piutang Tak Tertagih CV. Anugrah Sriwijaya Sukses pada tahun 2017 - 2019 (Dalam Rupiah)

\begin{tabular}{|c|c|c|c|}
\hline Tahun & $\begin{array}{c}\text { Jumlah Piutang Tak } \\
\text { Tertagih (Rp) }\end{array}$ & $\begin{array}{c}\text { Kenaikan Piutang } \\
\text { Tak Tertagih (Rp) }\end{array}$ & $\begin{array}{c}\text { Kenaikan Piutang } \\
\text { Tak tertagih (\%) }\end{array}$ \\
\hline 2015 & $1,096,274,935$ & & $0 \%$ \\
\hline 2016 & $1,301,358,567$ & $205,083,632$ & $16 \%$ \\
\hline 2017 & $1,769,397,940$ & $468,039,373$ & $26 \%$ \\
\hline 2018 & $2,532,224,950$ & $762,827,010$ & $27 \%$ \\
\hline 2019 & $3,485,632,950$ & $953,408,000$ & $20 \%$ \\
\hline
\end{tabular}

Sumber : Data internal CV. Anugrah Sriwijaya Sukses Palembang, 2020

Tabel 1 Berdasarkan tabel kita bisa melihat kenaikan piutang tak tertagih dengan data yang tidak tetap dimana terjadi kenaikan dan penurunan. Dimulai dari tahun 2015 jumlah piutang tak tertagih naik sebesar $16 \%$ per tanggal 31 desember 2016, per tanggal 31 desember 2017 naik kembali menjadi 26\% per tanggal 31 des 2017 naik sebesar $30 \%$ dan per 31 desember 2018 terjadi penurunan akan tetapi persentase masih lebih tinggi jika dibandingkan dengan periode 31 desember 2017 dengan presentase sebesar 27\%, dari hasil wawancara dengan bagian keuangan CV. Anugrah Sriwijaya Sukses mengungkapkan bahwa meningkatnya piutang tak tertagih yang tertunggak diakibatkan karena tingkat penjualan kredit yang meningkat dengan pesat dan pada bagian penagihan 
yang tidak tegas dalam menangani piutang tak tertagih, dan ada pula dari pihak penampung yang sengaja atau lalai untuk tidak melakukan pembayaran dikarenakan mengalami kesulitan dalam keuangan hal ini diungkapkan oleh akunting CV Anugrah Sriwijaya Sukses, apabila piutang tak tertagih terus meningkat dalam jumlah yang besar maka akan dapat mengurangi tingkat profitabilitas pada CV. Anugrah Sriwijaya Sukses.

Berdasarkan latar belakang masalah dan perumusan masalah yang telah diuraikan sebelumnya, maka tujuan penelitian ini adalah untuk menganalisis yang peyebab adanya piutang tak tertagih pada CV. Anugrah Sriwijaya Sukses, di antaranya: (1) Untuk mengetahui pengaruh rasio tunggakan, dan rasio penagih terhadap profitabilitas perusahaan; (2) Untuk mengetahui pengaruh rasio tunggakan terhadap profitabilitas CV. Anugrah Sriwijaya Sukses; (3) Untuk mengetahui pengaruh rasio penagih terhadap profitabilitas CV. Anugrah Sriwijaya Sukses.

\section{Tinjauan Literatur}

\subsection{Teori Perusahaan (Entity Theory)}

Menurut (Suwardjono, dalam Daka Purumas, 2014) mempersonifikasi badan usaha sebagai orang yang dapat melakukan perbuatan hukum dan ekonomi, misalnya dalam pembuatan kontrak dan kepemilikan aset. Menurutnya, sebagai konsekuensi dari konsep entitas, hubungan entitas dengan pemilik dipandang sebagai hubungan bisnis terutama dalam hak dan kewajiban atau utang piutang. Meskipun antara perusahan dengan pemiliknya terpisah, namun pemilik tetap berhak atas keuntungan yang harus diberikan oleh perusahaan dalam bentuk deviden. Laba bersih yang diperoleh dengan demikian bukanlah serta-merta adalah hak dari pemilik perusahaan. Diperlukan proses dalam menentukan dapat ditentukan kebijakan distribusi laba dalam bentuk deviden atau mengambil kebijakan untuk menahan laba, yang dikenal dengan laba ditahan yanng ditambahkan pada ekuitas pada posisi keuangan, yang secara substansi juga menambah kekayan dari pemilik perusahan itu sendiri. Teori ini dijelaskan untuk menjelaskan kedudukan keuangan atau saham yang terdapat pada CV. Anugrah Siwijaya Sukses.

\subsection{Teori Sinyal (Signaling Theory)}

Menurut (Lokollo dan Syahputra, dalam Marlinah, 2014) teori sinyal yaitu untuk memberikan sinyal yang positif berupa laporan keuangan yang baik pada pihak eksternal, maka perusahaan dapat memberikan informasi mengenai modal kerja dan rasio - rasio keuangan. Pemberi informasi - informasi ini dapat membuat pihak eksternal menjadi lebih yakin mengenai laba yang disajikan olah perusahaan dalam laporan keuangan adalah murni berupa hasil kinerja perusahaan demi memberikan sinyal positif bagi pihak eksternal. Berdasarkan pengertian teori diatas telah dijelaskan bahwa teori sinyal berfungsi untuk memberikan informasi mengenai modal kerja dan rasio - rasio keungan dimana dalam penelitian ini hasil dari perhitungan terhadap variabel independen dan variabel dependen mengunakan skala rasio.

\subsection{Analisa Laporan Keuangan}

Laporan keuanagan dibuat dengan maksud untuk memberikan gambaran atau laporan kemajuan (Progress report) secara periodik yang dillakukan oleh suatu perusahaan. Menurut (Brigham dan Houstun, 2013), Sifat laporan keuangan adalah menyajikan data historis serta menyeluruh yang terdiri dari data yang merupakan hasil kombinasi antara fakta yang telah dicatat (recorded fact), prinsip - prinsip dan kebiasaan di dalam akuntansi (accounting convention and postulated) serta pendapat pribadi (personal 
judgement). Untuk itu ada beberapa aspek dalam laporan keuangan yang dianggap penting dan perlu mendapatkan perhatian khusus seperti piutang dan profitabilitas sehingga perlu dievaluasi serta dianalisis lebih lanjut.

\subsection{Pengertian Profitabilitas}

Profitablitas merupakan pengukuran yang akan memungkinkan seorang penganalisa untuk mengevaluasi tingkat earning dalam hubungannya dengan volume penjualan, jumlah aktiva dan investasi tertentu dari pemilik perusahaan (Syamsudin, 2012). (Brigham dan Houstun, 2013) mendefinisikan profitabiltas adalah suatu indikasi atas bagaimana margin laba suatu perusahaan berhubungan dengan penjualan, modal rata-rata, dan ekuitas saham rata-rata. Dari beberapa pengertian yang diungkapkan para ahli, dapat disimpulkan bahwa profitabilitas adalah perbandingan laba dengan aktiva atau modal yang menghasilkan laba selama periode tertentu. Adapun jenis - jenis profitabilitas dalam buku (Sartono, 2012) Gros Profit Margin digunakan untuk mengukur kemampuan perusahaan menghasilkan laba melalui persentase laba kotor dari penjualan perusahaan: (1) Net Profit Margin digunakan untuk mengetahui laba bersih dari penjualan stelah dikurangi pajak; (2) Profit Margin digunakan untuk menghitung laba sebelum pajak dibagi total penjualan; (3) Rturn On Investment atau Return On Asset menunjukan kemampuan perusahaan menghasilkan laba dari aktiva yang dipergunakan; (4) Return On Equity mengukur kemampuan perusahaan memperoleh laba yang tersedia bagi pemegang saham perusahaan.

\subsection{Piutang}

Menurut (Hery, 2015) mendefinisikan Istilah piutang adalah "mengacu pada sejumlah tagihan yang akan diterima oleh perusahaan (umumnya dalam bentuk kas) dari pihak lain, baik sebagai akibat penyerahan barang dan jasa secara kredit". Sedangkan menurut (Diana dan Setiawati, 2017) Piutang merupakan asset keuangan yang berbentuk hak kontraktual untuk menerima kas dari entitas lain. Dari beberapa pengertian diatas dapat ditarik kesimpulan bahwa, piutang adalah aktiva lancar yang dimilik perusahaan yang timbul karena adanya penjualan secara kredit yang dilakukan oleh pihak perusahaan kepada pihak lain. Rasio - rasio yang berhubungan dengan piutang dagang pengertian rasio tunggakan: (1) Rasio tunggakan menurut Keown dalam (Kewon, dalam Diana, Noviana, 2016) rasio tunggakan ini dapat digunakan untuk mengetahui berapa besar jumlah piutang yang telah jatuh tempo dari sejumlah penjualan kredit yang belum tertagih; (2) pengertian rasio penagih, menurut Keown dalam (Kewon, dalam Diana, Noviana, 2016) rasio penagihan bertujuan untuk mengetahui berapa besar piutang yang tertagih dari total piutang yang dimiliki perusahaan.

\subsection{Hipotesis}

Menurut (Sugiyono, 2012) menyatakan bahwa hipotesis merupakan jawaban sementara terhadap rumusan masalah penelitian, dimana rumusan masalah penelitian telah dinyatakan dalam bentuk kalimat pertanyaan. Dikatakan sementara, karena jawaban yang diberikan baru didasarkan pada teori yang relevan, belum didasarkan pada fakta-fakta empiris yang diperoleh melalui pengumpulan data. Jadi hipotesis juga dapat dinyatakan sebagai jawaban teoritis terhadap rumusan masalah penelitian, belum jawaban yang empiris.

Berdasarkan kajian teori yang telah dijabarkan, maka hipotesis dari penelitian ini adalah: 
$\mathrm{H}_{1}$ : Rasio tunggakan dan rasio penagih berpengaruh terhadap profitabilitas (ROA) pada CV. Anugrah Sriwijaya Sukses.

$\mathrm{H}_{2}$ : Rasio tunggakan berpengaruh terhadap profitabilitas (ROA) pada CV. Anugrah Sriwijaya Sukses.

$\mathrm{H}_{3}$ : $\quad$ Rasio penagih berpengaruh terhadap profitabilitas (ROA) pada CV. Anugrah Sriwijaya Sukses.

\section{Metode Penelitian}

Penelitian ini menggunakan pengambilan data dengan teknik purposive sampling (Fauzi, Dencik \& Asiati, 2019), dengan metode analisis deskriptif kuantitatif dan pengukuran menggunakan bantuan SPSS versi 25. Penelitian ini dilakukan di CV. Anugrah Sriwijaya Sukses Palembang terletak di Jl. Kolonel Sulaiman Amin, Perum. Mustika Perdana, Sumatera selatan. Jenis data dari penelitian ini mengunakan jenis data primer dan data sekunder Data primer diperoleh sebagai hasil wawancara langsung dengan pimpinan perusahaan dan beberapa karyawan (bagian keuangan, bagian akuntansi) pada CV. Anugrah Sriwijaya Sukses Palembang Sumatera Selatan. Data sekunder yaitu data yang diperoleh dari dokumen-dokumen dan bahan tertulis yang berasal dari dalam perusahaan. Sumber data penelitian ini diperoleh dari kantor CV. Anugrah Sriwijaya Sukses dengan menerapkan kedua jenis data yaitu data primer dan data sekunder, dengan demikian data yang diperoleh dengan cara wawancara langsung dengan pimpinan perusahaan dan pihak yang berkaitan langsung dengan bagian akunting dan pencatatan piutang, dan melihat secara langsung data - data laporan keuangan CV. Anugrah Sriwijaya Sukses. Analisis pada penelitian ini menggunakan analisis deskriptif kuantitatif yaitu teknik analisis pengelolaan data berbentuk angka (numeric).

Piutang terjadi akibat adanya transaksi penjualan secara kredit. Pada prosesnya, piutang yang telah jatuh tempo tidak terbayarkan sehingga menimbulkan yang namanya piutang tak tertagih pada CV.Anugrah Sriwijaya Sukses. Adanya penyebab yang mempengaruhi jumlah piutang tersebut adalah sebagai berikut: (1) Volume penjualan kredit; (2) Syarat pembayaran penjualan kredit; (3) Ketentuan dalam batasan kredit; (4) Kebijakan dalam pengumpulan piutang; (5) Kebiasaan membayar konsumen.

Rasio tunggakan ini digunakan untuk mengetahui berapa jumlah piutang yang telah jatu tempo dari sejumlah penjualan kredit yang dilakukan dari piutang yang belum tertagih. Menghitung rasio tunggakan:

$R T=\frac{\text { Jlh ptg. tertunggak pada aktiva periode }}{\text { Total piutang pada periode yang sama }} \times 100 \%$

Rasio penagih digunakan untuk mengetahui sejauh mana aktifitas penagiahan yang dilakukan atau berapa besar piutang yang tak tertagih dari total piutang yang dimiliki perusahaan. Rasio ini menunjukkan kemampuan perusahaan dalam melaksanakan kegiatan penagihan piutang. Menghitung Rasio Penagih:

Rasio Penagih $=\frac{\text { Jumlah piutang yang tertagih }}{\text { Total piutang }} \times 100 \%$

Rasio profitabilitas ini digunakan untuk mengukur sejauh mana kemampuan perusahaan CV Anugrah Sriwijaya Sukses memperoleh laba yang tersedia bagi pemegang saham 
perusahaan. Menghitung Rasio ROA:

ROA $=\frac{\text { Laba Bersih }}{\text { Total Aktiva }} \times 100 \%$

Setelah dilakukan perhitungan data dengan analisis rasio tunggakan, rasio penagih dan rasio return on asset.

\section{Hasil dan Pembahasan}

Setelah dilakukan perhitungan data dengan analisis rasio tunggakan, rasio penagih dan rasio return on asset maka didapat hasil untuk diuji dengan aplikasi SPSS versi 25 dengan data sebagai berikut:

Tabel 1. Data Untuk Diuji Menggunakan SPSS

\begin{tabular}{|c|c|c|c|c|}
\hline Tahun & Bulan & $\begin{array}{c}\text { Rasio } \\
\text { Tunggakan }(\%)\end{array}$ & $\begin{array}{c}\text { Rasio } \\
\text { Penagih } \\
(\%) \\
\end{array}$ & ROA $(\%)$ \\
\hline \multirow{12}{*}{2017} & Januari & 4,52 & 80,88 & 21,60 \\
\hline & Februari & 7,36 & 62,13 & 12,99 \\
\hline & Maret & 5,83 & 76,45 & 18,63 \\
\hline & April & 6,45 & 67,03 & 15,39 \\
\hline & Mei & 4,60 & 82,83 & 21,34 \\
\hline & Juni & 6,52 & 73,96 & 15,02 \\
\hline & Juli & 3,55 & 85,44 & 24,18 \\
\hline & Agustus & 4,42 & 94,13 & 20,78 \\
\hline & September & 6,10 & 64,66 & 15,60 \\
\hline & Oktober & 7,28 & 65,06 & 12,91 \\
\hline & November & 8,09 & 52,70 & 8,91 \\
\hline & Desember & 2,40 & 97,62 & 27,74 \\
\hline \multirow{12}{*}{2018} & Januari & 4,82 & 86,06 & 21,82 \\
\hline & Februari & 5,02 & 77,69 & 18,24 \\
\hline & Maret & 8,60 & 52,40 & 9,74 \\
\hline & April & 7,47 & 62,90 & 12,34 \\
\hline & Mei & 4,60 & 86,57 & 21,55 \\
\hline & Juni & 6,76 & 60,58 & 15,37 \\
\hline & Juli & 3,64 & 94,04 & 24,93 \\
\hline & Agustus & 5,07 & 71,04 & 18,17 \\
\hline & September & 7,60 & 63,44 & 12,44 \\
\hline & Oktober & 6,59 & 74,72 & 18,82 \\
\hline & November & 5,25 & 87,45 & 17,93 \\
\hline & Desember & 3,99 & 96,66 & 24,77 \\
\hline \multirow{3}{*}{2019} & Januari & 6,65 & 68,09 & 15,04 \\
\hline & Februari & 7,50 & 54,32 & 12,36 \\
\hline & Maret & 5,14 & 78,89 & 18,22 \\
\hline
\end{tabular}

Published by: 


\begin{tabular}{|c|c|c|c|c|}
\hline Tahun & Bulan & $\begin{array}{c}\text { Rasio } \\
\text { Tunggakan (\%) }\end{array}$ & $\begin{array}{c}\text { Rasio } \\
\text { Penagih } \\
(\%)\end{array}$ & ROA $(\%)$ \\
\hline & April & 6,01 & 65,35 & 15,30 \\
\hline & Mei & 5,04 & 86,50 & 18,84 \\
\hline & Juni & 7,10 & 64,24 & 12,39 \\
\hline & Juli & 5,10 & 72,89 & 18,55 \\
\hline & Agustus & 8,08 & 59,94 & 9,52 \\
\hline & September & 6,89 & 67,52 & 12,99 \\
\hline & Oktober & 5,06 & 80,18 & 18,42 \\
\hline & November & 6,51 & 68,08 & 15,92 \\
\hline & Desember & 5,07 & 94,91 & 18,01 \\
\hline
\end{tabular}

\subsection{Uji Persyaratan}

Uji Normalitas dengan Kolmogorov smirnovUntuk menguji data yang terdistribusi dengan normal, dalam penelitian ini pengujian normalitas dilakukan dengan menggunakan uji statistik Kolmogorov-smirnov. Data dapat dikatakan terdistribusi normal apabila nilai Asymp.sig (2-tailed)) lebih dari 0,05. Hasil uji normalitas dengan Kolmogorov-smirnov dalam penelitian ini dapat dilihat pada tabel berikut: Pada awal uji normalitas mengunakan uji Kolmogorov-Smirnov belum terdistribusi secara normal, hasil dapat dilihat pada tabel berikut:

\begin{tabular}{|l|r|r|r|r|}
\hline \multicolumn{7}{|c|}{ Tabel 2. Uji Normalitas dengan Kolmogorov SmirnovOne-Sample } \\
Kolmogorov-Smirnov Test
\end{tabular}

Dari tabel diatas data belum berdistribusi secara normal, untuk itu dapat ditransformasi agar menjadi normal. Alat transformasi yang digunakan yaitu akar kuadrat atau sqare root (SQRT). Berikut adalah hasil uji Kolmogorov-Smirnov setelah ditransformasikan: 
Tabel 3. Uji Normalitas dengan Kolmogorov Smirnov Setelah Transformasi

\begin{tabular}{|c|c|c|c|c|c|}
\hline \multicolumn{6}{|c|}{ One-Sample Kolmogorov-Smirnov Test } \\
\hline & & $\begin{array}{c}\text { Rasio } \\
\text { Tunggakan }\end{array}$ & $\begin{array}{c}\text { Rasio } \\
\text { Penagih }\end{array}$ & ROA & $\begin{array}{l}\text { Unstandardized } \\
\text { Residual }\end{array}$ \\
\hline \multicolumn{2}{|l|}{$\mathrm{N}$} & 36 & 36 & 36 & 36 \\
\hline \multirow{2}{*}{$\begin{array}{l}\text { Normal } \\
\text { Parameters }^{\mathrm{a}, \mathrm{b}}\end{array}$} & Mean & 2,399 & 8,592 & 4,102 & 0,00000000 \\
\hline & & 0,312 & 0,750 & 0,559 & 0,14943707 \\
\hline \multirow{3}{*}{$\begin{array}{l}\text { Most Extreme } \\
\text { Differences }\end{array}$} & Absolute & 0,118 & 0,119 & 0,121 & 0,087 \\
\hline & Positive & 0,109 & 0,119 & 0,091 & 0,087 \\
\hline & Negative & $-0,118$ & $-0,085$ & $-0,121$ & $-0,067$ \\
\hline \multicolumn{2}{|l|}{ Test Statistic } & 0,118 & 0,119 & 0,121 & 0,087 \\
\hline \multicolumn{2}{|c|}{ Asymp. Sig. (2-tailed) } & ,200c,d & ,200c,d & ,200c,d & ,200c,d \\
\hline \multicolumn{6}{|c|}{ a. Test distribution is Normal. } \\
\hline \multicolumn{6}{|c|}{ b. Calculated from data. } \\
\hline \multicolumn{6}{|c|}{ c. Lilliefors Significance Correction. } \\
\hline \multicolumn{6}{|c|}{ d. This is a lower bound of the true significance. } \\
\hline
\end{tabular}

Berdasarkan hasil output SPSS di atas diketahui nilai masing - masing Asymp. Sig (2tailed) variabel rasio tunggakan sebesar 0,200, variabel rasio penagih sebesar 0,200, variabel $R O A$ sebesar 0,200 telah berdistribusi secara normal karena masing - masing variabel memiliki probabilitas lebih besar dari 0,05. Maka sesuai dengan dasar pengambilan keputusan dalam uji Kolmogorov-Smirnov di atas dapat disimpulkan bahwa data terdistribusi normal. Dengan demikian, asumsi atau persyaratan normalitas dalam model regresi sudah terpenuhi.

\subsection{Uji Asumsi Klasik}

Berikut adalah hasil dari perhitungan data dengan menggunakan bantuan SPSS untuk perhitungan uji asumsi klasik dan dijelaskan sebagai berikut:

Uji multikolinearitas digunakan untuk meneliti keberadaan hubungan antara variabel bebas yang satu dengan variabel bebas lainnya. Variabel dalam penelitian ini dapat dikatakan terhindar dari multikolinearitas jika hasil uji menunjukkan VIF $<10$ dan nilai tolerance $>0,1$. Hasil uji multikolinearitas dalam penelitian ini dapat dilihat pada tabel berikut: 
Tabel 4. Uji Multikolinieritas

\begin{tabular}{|c|c|c|c|c|c|c|c|c|}
\hline \multicolumn{9}{|c|}{ Coefficients ${ }^{a}$} \\
\hline & \multirow{2}{*}{ Model } & \multicolumn{2}{|c|}{$\begin{array}{l}\text { Unstandardize } \\
\text { d Coefficients }\end{array}$} & \multirow{2}{*}{$\begin{array}{c}\begin{array}{c}\text { Standardized } \\
\text { Coefficients }\end{array} \\
\text { Beta }\end{array}$} & \multirow{2}{*}{$\mathrm{t}$} & \multirow{2}{*}{ Sig. } & \multicolumn{2}{|c|}{$\begin{array}{l}\text { Collinearity } \\
\text { Statistics }\end{array}$} \\
\hline & & B & $\begin{array}{l}\text { Std. } \\
\text { Error }\end{array}$ & & & & $\begin{array}{c}\text { Tolera } \\
\text { nce }\end{array}$ & VIF \\
\hline \multirow{3}{*}{1} & (Constant) & 6,016 & 1,113 & & 5,403 & 0,000 & & \\
\hline & $\mathrm{SQRT}_{\overline{\mathrm{X}} 1} \mathrm{RasioT}_{-}$ & $-1,371$ & 0,191 & $-0,765$ & $-7,175$ & 0,000 & 0,190 & 5,249 \\
\hline & $\mathrm{SQRT}_{\mathrm{X} 2}^{\mathrm{RasioP}}$ & 0,160 & 0,079 & 0,215 & 2,016 & 0,052 & 0,190 & 5,249 \\
\hline & & & a. Dep & Var & $\mathrm{DA}$ & & & \\
\hline
\end{tabular}

Berdasarkan data di atas dapat diketahui nilai VIF dan tolerance yang dihasilkan dalam pengujian untuk masing-masing variabel yaitu variabel Rasio Tunggakan memiliki nilai VIF sebesar 5,249 dan nilai tolerance sebesar 0,190, variabel Rasio Penagih memiliki nilai VIF sebesar 5,249 dan nilai tolerance sebesar 0,190, hal ini menjelaskan bahwa nilai VIF lebih kecil dari 10 dan nilai tolerance lebih besar dari 0,1, sehingga dapat dikatakan bahwa variabel dalam penelitian ini tidak mengandung multikolinearitas.

Uji heteroskedastisitas digunakan untuk mengetahui apakah model regresi dalam penelitian ini terjadi ketidaksamaan varian antara yang satu dengan yang lain. Hasil uji heteroskedastisitas dalam penelitian ini dapat dilihat pada gambar berikut:

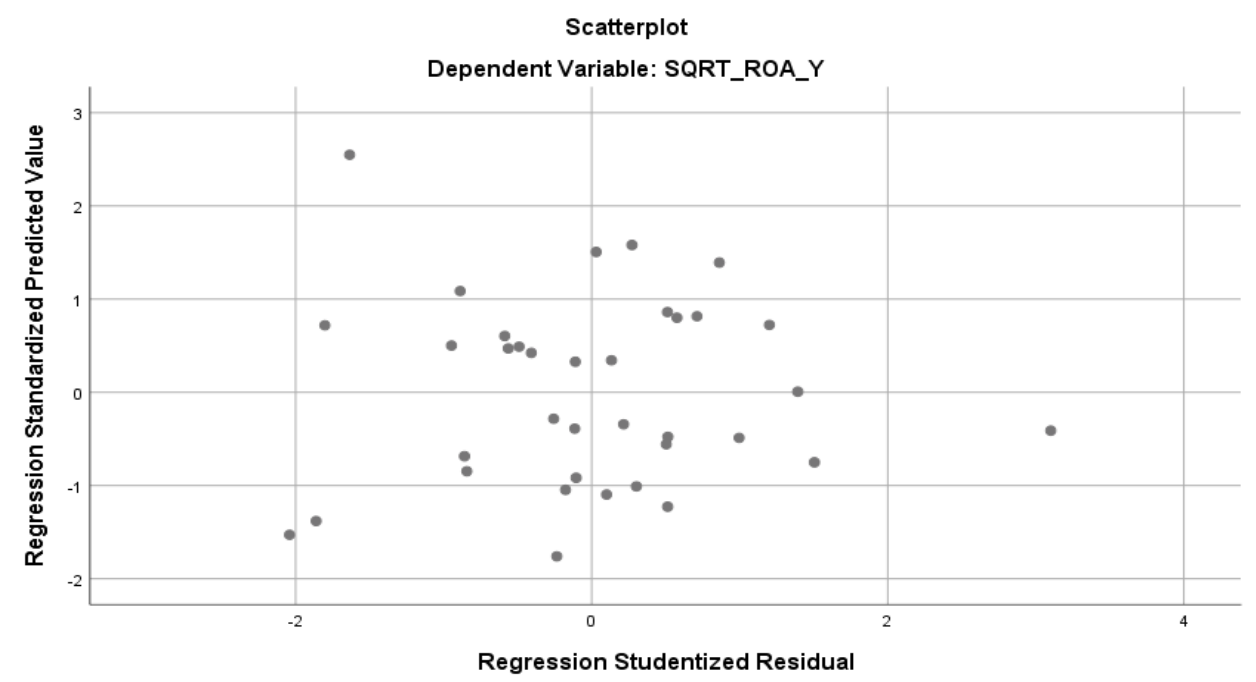

Gambar 4.1 Uji Heteroskedastisitas

Berdasarkan gambar di atas terlihat sebaran data ada di sekitar titik nol serta tidak tampak adanya suatu pola tertentu pada sebaran data tersebut, maka bisa disimpulkan bahwa model regresi bebas dari unsur heteroskedastisitas.

Uji auto korelasi digunakan untuk mendeteksi autokorelasi yaitu dengan melakukan uji run test. Run test merupakan bagian dari statistik nonparameterik yang dapat digunakan untuk melakukan pengujian, apakah antar residual terjadi korelasi yang tinggi. untuk 
Apabila nilai Asymp. Sig (2-tailed) Kurang dari 5\% atau 0,05, maka untuk $\mathrm{H}_{\mathrm{o}}$ tolak dan $\mathrm{H}_{\mathrm{a}}$ diterima. Hal tersebut berarti data residual terjadi secara tidak acak (Sitematis). Apabila nilai Asymp. Sig (2-tailed) lebih dari 5\% atau 0,05, maka untuk $\mathrm{H}_{\mathrm{o}}$ diterima dan $\mathrm{H}_{\mathrm{a}}$ ditolak. Hal tersebut berarti data residual terjadi secara acak (Random).

Tabel 5. Uji Autokorelasi

\begin{tabular}{|c|c|c|c|c|c|}
\hline \multicolumn{6}{|c|}{ One-Sample Kolmogorov-Smirnov Test } \\
\hline & & $\begin{array}{c}\text { Rasio } \\
\text { Tunggakan }\end{array}$ & $\begin{array}{l}\text { Rasio } \\
\text { Penagih }\end{array}$ & ROA & $\begin{array}{l}\text { Unstandardized } \\
\text { Residual }\end{array}$ \\
\hline \multicolumn{2}{|l|}{$\mathrm{N}$} & 36 & 36 & 36 & 36 \\
\hline \multirow{2}{*}{$\begin{array}{l}\text { Normal } \\
\text { Parameters }{ }^{\mathrm{a}, \mathrm{b}}\end{array}$} & Mean & 2,399 & 8,592 & 4,102 & 0,00000000 \\
\hline & & 0,312 & 0,750 & 0,559 & 0,14943707 \\
\hline \multirow{3}{*}{$\begin{array}{l}\text { Most } \\
\text { Extreme } \\
\text { Differences }\end{array}$} & Absolute & 0,118 & 0,119 & 0,121 & 0,087 \\
\hline & Positive & 0,109 & 0,119 & 0,091 & 0,087 \\
\hline & Negative & $-0,118$ & $-0,085$ & $-0,121$ & $-0,067$ \\
\hline \multicolumn{2}{|l|}{ Test Statistic } & 0,118 & 0,119 & 0,121 & 0,087 \\
\hline \multicolumn{2}{|c|}{ Asymp. Sig. (2-tailed) } & $200^{\mathrm{c}, \mathrm{d}}$ & $200^{\mathrm{c}, \mathrm{d}}$ & $200^{\mathrm{c}, \mathrm{d}}$ & $200^{\mathrm{c}, \mathrm{d}}$ \\
\hline \multicolumn{6}{|c|}{ a. Test distribution is Normal. } \\
\hline \multicolumn{6}{|c|}{ b. Calculated from data. } \\
\hline \multicolumn{6}{|c|}{ c. Lilliefors Significance Correction. } \\
\hline \multicolumn{6}{|c|}{ d. This is a lower bound of the true significance. } \\
\hline
\end{tabular}

Berdasarkan data diatas menunjukan bahwa data Asymp. Sig (-Tailed) variabel unstandardized residual sebesar 0,200 lebih besar dari 0,05 maka $\mathrm{H}_{\mathrm{o}}$ diterima dan $\mathrm{H}_{\mathrm{a}}$ ditolak hal ini meyatakan bahwa data terjadi secara acak (Random) tidak terjadi autokorelasi.

\subsection{Uji Regresi Linier Berganda}

Analisis regresi linier berganda digunakan untuk mengukur kekuatan hubungan antara dua variabel atau lebih dan juga menunjukkan arah hubungan antara variabel dependen dengan variabel independen. Hasil pengujian analisis regresi linier berganda dalam penelitian ini dapat dilihat pada tabel berikut:

Tabel 6 Hasil Uji Regresi Linier Berganda

\begin{tabular}{|c|c|c|c|c|c|c|c|c|}
\hline \multicolumn{9}{|c|}{ Coefficients $^{\mathrm{a}}$} \\
\hline & \multirow{2}{*}{ Model } & \multicolumn{2}{|c|}{$\begin{array}{l}\text { Unstandardized } \\
\text { Coefficients }\end{array}$} & \multirow{2}{*}{$\begin{array}{c}\text { Standardized } \\
\text { Coefficients }\end{array}$} & \multirow{2}{*}{$\mathrm{t}$} & \multirow{2}{*}{ Sig. } & \multicolumn{2}{|c|}{$\begin{array}{l}\text { Collinearity } \\
\text { Statistics }\end{array}$} \\
\hline & & B & $\begin{array}{l}\text { Std. } \\
\text { Error }\end{array}$ & & & & Tolerance & VIF \\
\hline \multirow{3}{*}{1} & (Constant) & 6,016 & 1,113 & & 5,403 & ,000 & & \\
\hline & SQRT_RasioT_X1 & $-1,371$ & 0,191 & $-0,765$ & $-7,175$ & ,000 & 0,190 & 5,249 \\
\hline & SQRT_RasioP_X2 & 0,160 & 0,079 & 0,215 & 2,016 & ,052 & 0,190 & 5,249 \\
\hline
\end{tabular}


Berdasarkan hasil perhitungan yang ada pada tabel di atas diperoleh hasil persamaan Regresi Linier Berganda sebagai berikut:

$Y=6,016+(-1,371) X_{1}+0,160 X_{2}$

Berdasarkan persamaan di atas diketahui nilai-nilai sebagai berikut:

Nilai konstanta $(\alpha)$ sebesar 6,016, yang artinya jika variable rasio tunggakan dan rasio penagih bernilai nol, maka rasio profitabilitas atau ROA (Y) akan bernilai 6,016. Nilai koefisien regresi untuk variabel rasio tunggakan $\left(\beta_{1}\right)$ sebesar -1,371 (berpengaruh negatif) yang artinya jika variabel rasio tunggakan mengalami peningkatan sebesar 1, maka hasil output profitabilitas atau ROA (Y) menurun sebesar -1,371. Nilai koefisien regresi untuk variabel rasio penagih $\left(\beta_{2}\right)$ sebesar 0,160 (berpengaruh positif) yang artinya jika variabel rasio penagih mengalami peningkatan sebesar 1 , maka hasil output rasio profitabilitas atau ROA (Y) meningkat sebesar 0,160.

\subsection{Uji Hipotesis}

Pengujian hipotesis dilakukan untuk mengetahui bagaimana pengaruh variabel independent terhadap variabel dependent baik secara parsial maupun secara bersamasama, yang mana untuk mengetahui hasil uji hipotesis ini dilakukan pengujian berikut ini:

Uji F (Uji Simultan), pengujian ini dilakukan untuk mengetahui apakah variabel bebas secara keseluruhan atau bersamaan berpengaruh pada variabel terikat. Variabel rasio tunggakan dan rasio penagih secara bersama-sama dapat dikatakan berpengaruh terhadap variabel profitabilitas (ROA) apabila nilai signifikansi yang dihasilkan lebih kecil dari nilai alpha $(<0,05)$ dan nilai $F_{\text {hitung }}>F_{\text {tabel }}$ maka hipotesis diterima dan sebaliknya apabila nilai signifikansi yang dihasilkan lebih besar dari nilai alpha $(>0,05)$ dan nilai $\mathrm{F}_{\text {hitung }}<$ $F_{\text {tabel }}$ maka hipotesis ditolak. Hasil pengujian hipotesis secara simultan dalam penelitian ini dapat dilihat pada tabel berikut:

Tabel 7. Hasil Uji F (Simultan)

\begin{tabular}{|l|l|c|c|c|c|c|}
\hline \multicolumn{7}{|c|}{ ANOVA $^{\text {a }}$} \\
\hline \multicolumn{2}{|c|}{ Model } & $\begin{array}{c}\text { Sum of } \\
\text { Squares }\end{array}$ & Df & $\begin{array}{c}\text { Mean } \\
\text { Square }\end{array}$ & F & Sig. \\
\hline \multirow{2}{*}{1} & Regression & 10,143 & 2,000 & 5,071 & 214,115 &, $000^{\text {b }}$ \\
\cline { 2 - 7 } & Residual & 0,782 & 33,000 & 0,024 & & \\
\cline { 2 - 7 } & Total & 10,924 & 35,000 & & & \\
\hline \multicolumn{7}{|l}{ a. Dependent Variable: SQRT_ROA_Y } \\
\hline
\end{tabular}

Berdasarkan tabel di atas dapat diketahui nilai signifikan yang dihasilkan dalam pengujian ini sebesar 0,000 yang mana nilai tersebut lebih kecil dari 0,05 dan nilai $F_{\text {hitung }}$ 214,115 yang mana nilai tersebut lebih besar dari $F_{\text {tabel }} 3,28$. Hal ini berarti hipotesis diterima dan menunjukkan bahwa variabel rasio tunggakan dan rasio penagih secara bersama-sama berpengaruh dan signifikan terhadap variabel profitabilitas (ROA).

Uji t(Uji Parsial), pengujian ini dilakukan untuk mengetahui tingkat pengaruh setiap satu variabel bebas terhadap variabel terikat. Sebuah variabel bebas dapat dikatakan 
berpengaruh pada variabel terikat apabila nilai signifikansi yang dihasilkan dalam pengujian pada tiap-tiap variabel bebas lebih kecil dari nilai alpha $(<0,05)$ dan nilai $t_{\text {hitung }}>t_{\text {tabel }}$ maka hipotesis akan diterima dan sebaliknya apabila nilai signifikansi yang dihasilkan dalam pengujian pada tiap-tiap variabel bebas lebih besar dari nilai alpha ( $>$ $0,05)$ dan nilai thitung $<\mathrm{t}_{\text {tabel }}$ maka hipotesis akan ditolak. Hasil pengujian hipotesis secara parsial dalam penelitian ini dapat dilihat pada tabel berikut:

Tabel 8 Hasil Uji T (Parsial)

\begin{tabular}{|r|c|c|c|c|c|c|}
\hline \multirow{2}{*}{\multicolumn{2}{|c|}{ Model }} & \multicolumn{2}{|c|}{$\begin{array}{c}\text { Unstandardized } \\
\text { Coefficients }\end{array}$} & $\begin{array}{c}\text { Standardized } \\
\text { Coefficients }\end{array}$ & \multirow{2}{*}{ T } & \multirow{2}{*}{ Sig. } \\
\cline { 3 - 5 } & B & $\begin{array}{c}\text { Std. } \\
\text { Error }\end{array}$ & Beta & & \\
\hline \multirow{2}{*}{1} & (Constant) & 6,016 & 1,113 & & 5,403 &, 000 \\
\cline { 2 - 7 } & SQRT_RasioT_X1 & $-1,371$ & 0,191 & $-0,765$ & $-7,175$ &, 000 \\
\cline { 2 - 6 } & SQRT_RasioP_X2 & 0,160 & 0,079 & 0,215 & 2,016 & \multirow{2}{*}{, 052} \\
\hline
\end{tabular}

Berdasarkan tabel di atas dapat diketahui nilai signifikan dan thitung yang dihasilkan dalam pengujian untuk masing-masing variabel yaitu:

Variabel rasio tunggakan memiliki nilai signifikan sebesar 0,000 lebih kecil dari 0,05 dan nilai $t_{\text {hitung }}$ sebesar -7,175 lebih kecil dari tabel yaitu 2,03452. Hal ini menunjukkan bahwa variabel rasio tunggakan berpengaruh negatif dan signifikan terhadap variabel profitabilitas (ROA). Variabel modal rasio penagih memiliki nilai signifikan sebesar 0,052 lebih besar dari 0,05 dan nilai thitung sebesar 2,016 lebih kecil dari tabel yaitu 2,0345. Hal ini menunjukkan bahwa variabel rasio penagihan tidak berpengaruh terhadap variabel profitabilitas (ROA).

Uji koefisien determinasi berguna untuk mengetahui seberapa besar variabel independen mampu menjelaskan variabel dependen. Hasil pengujian koefisien determinasi dalam penelitian ini dapat dilihat pada tabel berikut:

Tabel 9. Hasil Uji Koefisien Determinasi $\left(R^{2}\right)$

\begin{tabular}{|c|c|c|c|c|}
\hline \multicolumn{5}{|c|}{ Model Summary $^{\mathbf{b}}$} \\
\hline Model & $\mathrm{R}$ & R Square & Adjusted R Square & $\begin{array}{c}\text { Std. Error of the } \\
\text { Estimate }\end{array}$ \\
\hline 1 &, $964^{\mathrm{a}}$ &, 928 &, 924 & 0.154 \\
\hline \multicolumn{4}{l}{} \\
\hline
\end{tabular}

Berdasarkan tabel di atas dapat diketahui nilai Adjusted $R$ square sebesar 0,924, sehingga dapat diketahui bahwa variabel independen dalam penelitian ini yang meliputi rasio tunggakan dan rasio penagih mampu menjelaskan tentang variabel profitabilitas (ROA) sebesar 0,924 atau $92,4 \%$ artinya sebesar $7,6 \%$ dijelaskan oleh variabel lain di luar penelitian ini. 


\subsection{Pembahasan}

Pengaruh Rasio Tunggakan dan Rasio Penagih Dari data Piutang Tak Tertagih Terhadap Profitabilitas CV. Anugrah Sriwijaya Sukses: Variabel rasio tunggakan dan rasio penagih memiliki nilai signifikan sebesar 0,000 yang mana nilai tersebut lebih kecil dari 0,05 dan nilai $F_{\text {hitung }}$ sebesar 214,114 yang mana nilai tersebut lebih besar dari nilai $\mathrm{f}_{\text {tabel }}$ sebesar 3,28 sehingga $\mathrm{H}_{1}$ diterima, artinya bahwa rasio tunggakan dan rasio penagih secara bersama-sama berpengaruh terhadap profitabilitas (ROA) pada CV. Anugrah Sriwijaya Sukses.

Hasil penelitian ini berhubungan dengan hasil penelitan dari Andika Prasetya Nugraha dan Safitri (2019) dimana dalam kesimpulan diadapat hasil profitabilitas secara simultan berpengaruh terhadap variabel bebas piutang tak tertagih. Hal tersebut sejalan jika dibandingkan dengan teoritis. Secara teori dikatakan bahwa piutang tak tertagih berpengaruh terhadap profitabilitas. Sebab dengan memberikan piutang berarti perusahaan memberikan kesempatan danannya berputar untuk memperoleh laba lebih banyak lagi jumlah laba. Riyatno dalam Anugrah (2019).

Dalam hal ini teori yang menjelaskan tentang Business entity Concept atau dalam literatur-literatur teori akuntansi dikenal dengan entity theory digagas oleh Paton (1962) dalam Daka Purumas (2014) bahwa dengan adanya entity theory perusahaan dengan pemiliknya menjadi terpisah. Kepemilikan aset dimiliki oleh perusahaannya, dan antara kewajiban dengan pemegang ekuitas oleh investor dalam aset tersebut merupakan hak yang berbeda. Atas dasar konsep ini maka dapat dirumuskan dalam posisi keuangan bahwa aset sama dengan jumlah kewajiban ditambah dengan ekuitas pemilik. Teori ini digunakan untuk menjelaskan kedudukan atau saham pada CV. Anugrah Sriwijaya Sukses. Dan dalam teori sinyal menurut (Lokollo dan Syahputra, 2013 dalam Marlinah, 2014) teori sinyal yaitu untuk memberikan sinyal yang positif berupa laporan keuangan yang baik pada pihak eksternal, maka perusahaan dapat memberikan informasi mengenai modal kerja dan rasio - rasio keuangan. Pemberi informasi - informasi ini dapat membuat pihak eksternal menjadi lebih yakin mengenai laba yang disajikan olah perusahaan dalam laporan keuangan adalah murni berupa hasil kinerja perusahaan demi memberikan sinyal positif bagi pihak eksternal.

Dalam kinerja keuangan perusahaan CV. Anugrah Sriwijaya Sukses secara simultan rasio tunggakan dan rasio penagih berpengaruh terhadap profitabilitas perusahaan, apabila rasio - rasio pengaruh piutang tak tertagih terus mempengaruhi profitabilitas perusahaan maka dapat memberikan dampak yang tidak baik terhadap sinyal yang diberikan kepada pihak investor.

Pengaruh Rasio Tunggakan Terhadap Profitabilitas CV. Anugrah Sriwijaya Sukses: Variabel rasio tunggakan memiliki nilai signifikan sebesar 0,000 yang mana nilai tersebut lebih kecil dari 0,05 dan nilai thitung sebesar -7,175 yang mana nilai tersebut lebih kecil dari nilai tabel sebesar 2,03452 sehingga $\mathrm{H}_{1}$ diterima, artinya bahwa rasio tunggakan berpengaruh negatif dan signifikan terhadap profitabilitas pada perusahaan CV. Anugrah Sriwijaya Sukses. Dimana semakin naiknya rasio tunggakan maka semakin turun nilai profitabilitas pada CV. Anugrah Sriwijaya Sukses.

Pengaruh Rasio Penagih Terhadap Profitabilitas CV. Anugrah Sriwijaya Sukses: Variabel rasio penagih terhadap profitabilitas atau return on asset memiliki nilai signifikan sebesar 0.052 yang mana nilai tersebut lebih besar dari 0,05 dan nilai $t_{\text {hitung }}$ sebesar 2.016 yang 
mana nilai tersebut lebih kecil dari nilai $\mathrm{t}_{\text {tabel }}$ sebesar 2,0345 sehingga $\mathrm{H}_{3}$ ditolak, artinya rasio penagih tidak berpengaruh terhadap profitabilitas CV. Anugrah Sriwijaya Sukses. Dalam artian bahwa dari bagian penagihan pada CV. Anugrah Sriwijaya Sukses masih konsisten dengan bagian penagihannya.

\section{Kesimpulan}

Berdasarkan hasil pengolahan data yang telah dijabarkan pada bab sebelumnya, dengan demikian dapat ditarik kesimpulan mengenai hasil penelitian ini sebagai berikut: (1) Rasio tunggakan dan rasio penagih berpengaruh terhadap profitabilitas (ROA) pada perusahaan CV. Anugrah Sriwijaya Sukses. Dibuktikan dari uji f simultan dengan nilai signifikan 0,000 yang mana nilai tersebut lebih kecil dari 0,05 dan nilai $F_{\text {hitung }} 214,115$ yang mana nilai tersebut lebih besar dari $\mathrm{F}_{\text {tabel }} 3,28$. Hal ini berarti hipotesis diterima dan menunjukkan bahwa variabel rasio tunggakan dan rasio penagih secara bersama-sama berpengaruh terhadap variabel profitabilitas $(R O A)$ pada CV. Anugrah Sriwijaya Sukses; (2) Rasio tunggakan berpengaruh negatif dan signifikan dibuktikan dari hasil uji t parsial dengan nilai signifikan sebesar 0,000 lebih kecil dari 0,05 dan nilai thitung sebesar -7,175 lebih kecil dari tabel yaitu 2,03452. Hal ini menunjukkan bahwa variabel rasio tunggakan berpengaruh negatif dan signifikan terhadap variabel profitabilitas (ROA) pada CV. Anugrah Sriwijaya Sukses; (3) Rasio penagih tidak berpengaruh terhadap profitabilitas perusahaan CV. Anugrah Sriwijaya Sukses hal ini dibuktikan dari hasil pengukuran uji t parsial dengan nilai signifikan sebesar 0,052 lebih besar dari 0,05 dan nilai thitung sebesar 2,016 lebih kecil dari tabel yaitu 2,0345. Hal ini menunjukkan bahwa variabel rasio penagih tidak berpengaruh terhadap variabel profitabilitas (ROA) pada CV. Anugrah Sriwijaya Sukses.

Hendaknya piutang dikendalikan dan dikelola dengan sebaik mungkin oleh bagian administrasi atau penatausahaan piutang agar tingkat perputaran piutang menjadi lebih baik, sehingga persentase penagihan dapat terus meningkat dan sebaiknya mengurangi jumlah piutang yang tertunggak untuk mencegah timbulnya resiko piutang. Untuk mengatasi dampak piutang tak tertagih pada perusahaan, CV. Anugrah Sriwijaya Sukses sebaiknya pihak manajemen melakukan pembedahan terhadap prosedur yang telah ada untuk meminimalkan resiko tidak dijalankannya prosedur, serta tetap menggunakan metode peyisihan, dalam antisipasi kerugian piutang untuk menjaga keamanan kondisi keuangan perusahaan.

\section{Referensi}

Brigham \& Houston. (2013). Dasar - Dasar Manajemen Keuanagn. Jakarta: Salemba Empat.

Diana \& Setiawati. (2017). Akuntansi Keuangan Menengah. Yogyakarta: Andi Offset.

Fauzi, F., Dencik, A. B., \& Asiati, D. I. (2019). Metodologi Penelitian Untuk Manajemen dan Akuntansi. Jakarta: Salemba Empat.

Hery. (2015). Analisis Laporan Keuangan . Yogyakarta: IAI.

Hery, dalam Egam dkk. (2017). Pengaruh Return On Asset (ROA), Return On Equity (ROE), Net Profit Margin (NPM), dan Earning Per Share (EPS) terhadap harga saham perusahaan yang tergabung dalam Indeks LQ45 di Bursa Efek Indonesia periode tahun 2013-2015. Jurnal EMBA, 107. 
Kewon, dalam Diana, Noviana. (2016). Analisis tingkat perputaran piutang pada PT Perdana Gapuraprima periode 2012-2014. Jurnal. Universitas Bakrie, 410.

Lokollo \& Syahputra, dalam Marlinah. (2014). Pengaruh Dana Pihak Ketiga (DPK) Dan Rasio Keuangan Terhadap Profitabilitas Bank Syariah Dengan Pembiayaan Sebagai Variabel Intervening Periode 2015-2018. Skripsi, IAIN, 17-18.

Riyanto, dalam Iskandar. (2016). Analisis profitabilitas terhadap tingkat perputaran berkelanjutan pada koperasi karyawan PT. Telkom Makasar. Jurnal. STIE YPUP MAKASAR, 36.

Rositah, H. (2018). Pengaruh beban piutang tak tertagih terhadap Return On Assets (Studi pada PT PLN (Persero) Distribusi Jawa Timur Area Malang pada periode tahun 2009 2016). Jurnal Administrasi Bisnis, 151.

Sartono, A. (2012). Manajemen Keuangan Teori Aplikasi (Vol. IV). Yogyakarta: BPFE.

Sugiyono. (2012). Memahami Penelitian Kualitatif. Bandung: Alfabeta.

Suwardjono, dalam Daka Purumas. (2014). Pengaruh Return On Asset, Debt To Equity Ratio dan Curent Ratio Terhadap Return Saham (Survei Pada Perusahaan Sektor Pertambangan Yang Terdaftar di Bursa Efek Indonesia Periode 2009-2013. Tesis. Universitas Widyatama, 11.

Syamsudin, L. (2012). Dasar - Dasar Manajemen Keuanagan. Jakarta: PT. Raja Grafindo Persada

\section{Copyrights}

Copyright for this article is retained by the author(s), with first publication rights granted to the journal.

This is an open-access article distributed under the terms and conditions of the Creative Commons Attribution license (http://creativecommons.org/licenses/by/4.0/) 